\title{
Mortality of newspaper workers from lung cancer and bronchitis 1952-66
}

\author{
E. MOSS, T. S. SCOTT, and G. R. C. ATHERLEY' \\ Department of Occupational Health, University of Manchester
}

\begin{abstract}
Moss, E., Scott, T. S., and Atherley, G. R. C. (1972). Brit. J. industr. Med, 29, 1-14. Mortality of newspaper workers from lung cancer and bronchitis 1952-66. The mortality experience of 3485 men who worked full-time in the newspaper printing industry in London and Manchester and died in the period 1952-66 has been analysed for occupation and cause of death.

There was an excess of deaths from cancer of the lung and bronchus (I.C.D. 162,163) in printing trade workers as a whole compared with the male population of the region in which they worked, adjusted for age and calendar year of death. The excess was about $30 \%$ in London and about $40 \%$ in Manchester. Both these excesses are significant at the $1 \%$ level. In Manchester, but not in London, there was a concentration of excess (about $100 \%$ ) in machine room men, again significant at the $1 \%$ level. White collar workers showed no difference between observed and expected deaths in London and only a small excess $(20 \%$, not significant at the $5 \%$ level) in Manchester.

There were small deficits of deaths from bronchitis (I.C.D. 500 to 502 ), about $10 \%$ for printing trade workers, and 30 to $40 \%$ for white collar workers, with little difference between London and Manchester. Neither deficit is significant at the $5 \%$ level because of the small numbers involved.

This survey does not provide any evidence about the cause of the overall small excess of deaths from lung cancer, which might or might not be occupational. The larger excess in the Manchester machine room men is more likely to be due to an occupational hazard.
\end{abstract}

The Registrar General's 1931 Decennial Supplement for England and Wales noted that printing machine minders, printers, and machine rulers showed an excess of deaths from cancer of the lung $(16$ compared with 10 standard deaths) which was probably significant. In the 1951 Supplement, this group had a normal mortality experience, while deaths of compositors from lung cancer were below expectation. In a study covering many occupations Kennaway and Kennaway (1947) found that certified deaths from lung cancer of printers in England and Wales during the period 1921-38 were 177, the expected number

${ }^{1}$ Present address: University of Aston. being 148.5 and the population of printers about 83000 .

In 1955 Ask-Upmark attempted to relate the increase in lung cancer in Sweden to the growth of newspaper reading. He found more printing workers among the cases of bronchial carcinoma in a clinic in Stockholm than he expected on rather unsubstantial grounds from the number of typographers in the population of Stockholm.

In a prospective study of mortality of several occupational groups, in which an allowance was made for smoking habits as well as for age, Dunn and Weir (1968) reported after five years a marked deficit in the incidence of lung cancer among workers in the printing industry in California, U.S.A., but 
after a further two and a half years the deficit was much less marked and no longer statistically significant (30 recorded deaths against 38.6 expected over seven and a half years).

In 1966 the limited information available in two Manchester newspaper companies was examined and it appeared that the numbers of machine room men who had died from lung cancer in both companies were probably greater than would have been expected from the figures for the male population of England and Wales in the same age groups and years as given in the Registrar General's returns.

These reports and findings indicated that a more extensive survey of newspaper printing companies was required. In the investigation here reported the causes of death in the various occupational groups of 16 companies in London and Manchester have been compared with those in the Registrar General's statistics for the areas in which the companies are located.

\section{The survey}

Eleven London and five Manchester companies supplied, so far as could be done from their records, the name, address, occupation, age, and date of death of all employees and ex-employees known to have died in the years 1952-67. Four companies included some dates of death before 1952, and the dates of death in 1967 were incomplete.

The names of 4430 male employees who had died were provided by the companies, mostly from Pension Fund records (Table 1). This number was reduced to 4030 by the exclusion of men who died in 1967 and by the removal of duplications and uncertainties and of the names of men whose causes of death could not be traced. Several men were employed by more than one company and some names appeared in up to four lists. All the duplicated entries were identified and the duplications eliminated. The causes of death of 79 men could not be traced $(1.9 \%$

\section{TABLE 1}

Total no. of returns (male)
Date of death in 1967

No. of returns to 31 Dec. 1966

Exclusions:

(a) Duplicated in company's records

(b) Identified in other companies' records

(c) Insufficient information, worked outside U.K., died abroad and death certificate not available, 1 female, 1 still alive,

No. of eligible returns

Cause of death not traced (1.9\%)

No. finally available

Date of death before 1 Jan. 1952

Worked less than 4 shifts

No. of males who worked 4 shifts or more

and died between 1 Jan. 1952 and 31 Dec. 1966

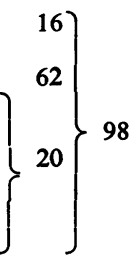

79 $\left.\begin{array}{l}173 \\ 372\end{array}\right\} 545$

4109

4030

3485 of those sought). The lists were possibly incomplete because not all employees were in Pension Funds or on other records but, in view of the inclusive nature of the Pension Funds, this is unlikely to have a marked effect on the data.

A further reduction in numbers was made by excluding the deaths before 1952, so that the data could be considered over three quinquennia, 1952-56, 1957-61, and 1962-66. In several of the companies a considerable number of men (372 in all) worked less than four shifts per week and were also excluded. No distinction has been made between day and night shifts, nor has it been possible in this broad survey to ascertain total years of exposure. It is considered likely, however, that most men engaged full-time in the industry have spent much, if not all, of their working life there. The final number of men who had worked four or more shifts per week in the newspaper industry and who died between 1 January 1952 and 31 December 1966 was 3 485; of these, 2679 worked in London and 806 in Manchester.

The certified causes of death for each man were obtained from the records of the Registrar General. Some death certificates were held elsewhere than in London and further searches were required. Information, usually about retired men, had to be sought as far afield as the United States, Australia, and New Zealand.

The occupations were divided into the five categories given below. The figures in parentheses are the total number of deaths in each category.

\section{Printing trade workers}

1. Compositors, readers, and foundrymen (760)

2. Machine room men (740)

3. Publishing room men (736)

4. Other manual workers (production and maintenance) (415)

\section{White collar workers}

5. Office workers and staff (834)

The main occupations included in the five job categories are listed in Appendix A. The printing trade jobs were so grouped that the first three categories had each a common or associated environment. Compositors, readers, and foundrymen deal with the production and correction of the type, and the machine room men with the actual printing of the paper. The publishing room men parcel up the newspapers and prepare the bundles for distribution. Category 4 included jobs with more varied working conditions.

The occupation entered on the death certificate was usually that given to the Registrar by relatives and the Registrar General in his returns acknowledges that his sources are inclined to be unreliable. In those cases in which the records disagreed, therefore, the occupation given by the employer was taken as likely to be more accurate.

On the other hand, where there was any discrepancy in the age at death, the age given on the death certificate was preferred. Moreover, the Registrar General uses this age in compiling the overall mortality statistics, with which comparisons have been made.

The causes of death were classified according to the International Classification of Diseases (Seventh Revision) in use by the Registrar General at the date of death so that a direct comparison with his mortality 
statistics can be made. The information on the death certificates was unsatisfactory in 36 cases. Reference to original hospital records yielded complete information in 29 of these; the remaining seven had to be coded simply according to the coding rules.

The groupings used were as follows:

A. Cancer of lung and bronchus (I.C.D. 162, 163)

B. All malignant diseases except A (I.C.D. 140-205 !ess 162,163 )

C. Other diseases of respiratory system including bronchitis (I.C.D. 470-527)

D. Diseases of heart and circulatory system (I.C.D. 400-468)

E. Diseases of nervous system (I.C.D. 330-398)

F. All other causes of death including accidents and suicides.

In 38 of the 3485 death certificates malignant disease was mentioned in a subsidiary role and, in accordance with the coding rules, was not coded as the underlying cause of death. Six of the 38 cases mentioned cancer of the lung and bronchus; coding as such would have had a negligible effect on the results and the conclusions drawn from them (see Appendix B).

All the relevant information about each man was coded and entered on punched cards for mechanical sorting and statistical analysis. The aim of the analysis was, for each company, to compare the deaths from cancer of the lung in each of the five occupational groups with the Registrar General's statistics for the whole male population of the specific region in which each newspaper company is situated. The appropriate regions are Greater London for the London companies and the South East Lancashire Conurbation for the Manchester companies.

As the number of men who worked in each job, i.e., the population at risk, is not known, mortality rates (the number of deaths from a given cause per 1000 living in the population) cannot be calculated. It is necessary, therefore, to use proportional mortalities (the number of deaths caused by the disease of interest expressed as a proportion of all deaths). The disadvantage of proportional mortalities is that they are not independent of deaths in the population at risk due to other causes, whereas mortality rates are.

\section{Results}

In Table 2 the absolute numbers of deaths and the percentage of deaths from each cause in each job category are given for the combined London companies and the combined Manchester companies. Taking each of the six grouped causes of death separately and comparing the proportions of deaths from that cause in the four printing trade job categories with one another, the differences are statistically significant only for cancer of the lung and bronchus in the Manchester companies $\left(\chi^{2}=13.94\right.$, D.F. $\left.=3, \quad \mathbf{P}<0.01\right)$, the machine room men having the highest proportion of deaths from lung cancer (18.9\% of all deaths).

The differences between the four job categories for heart and circulatory diseases in the combined Manchester companies are significant at the 5\% level but not at the $1 \%$ level $\left(\chi^{2}=10 \cdot 19\right.$, D.F. $=3$, $0.05>\mathrm{P}>0.01$ ).

None of the other disease groups in the Manchester companies and none of the six disease groups in the London companies show statistically significant differences between the four printing trade job categories even at the $5 \%$ level.

The white collar workers had lower percentages of deaths from cancer of the lung and bronchus and from other respiratory diseases (including bronchitis) than the combined printing trade workers in both the London and the Manchester companies. The differences are statistically significant in the London companies (lung cancer, $\chi^{2}=4 \cdot 75$, D.F. $=1$, $0.05>P>0.01$; other respiratory diseases, $\chi^{2}=9.82$, D.F. $\left.=1, P<0.01\right)$ but are not significant at the $5 \%$ level in the Manchester companies. The differences between white collar workers and printing trade workers in the percentages of deaths from the other four disease groups are relatively small and are not statistically significant.

\section{Deaths from cancer of lung and bronchus}

The percentages quoted in Table 2 are not corrected for differences in the ages at death or in the calendar dates of death. To take these factors into account it is necessary to calculate expected numbers of deaths in each age group and calendar period. This has been done for deaths from cancer of the lung and bronchus for each job category in 13 of the individual companies. The numbers of deaths in three of the London companies (07 to 09) were too small to be treated separately and have been combined, giving a total of 14 companies or company groups.

The expected numbers of deaths are the numbers of deaths in the job categories in each company which would have occurred if the ratio of deaths from cancer of the lung and bronchus to all deaths, among newspaper workers, had been the same at each age and date of death as that of the whole male population of the region in which they worked. For example, there were 33 deaths from all causes among publishing room men from the London company (01) aged 55 to 64 at death in the five-year period 1962-6. The percentage of deaths from cancer of the lung and bronchus in the male population of Greater London at the same age of death and calendar period was $16.47 \%$. The expected number of deaths from cancer of the lung and bronchus was, therefore, $\frac{33 \times 16.47}{100}=5 \cdot 44$. The observed number

of lung cancer deaths in the 33 deaths of publishing room men was six. The expected numbers of deaths at each age of death and calendar period were then added together to give the total expected number for each job category in each company 
TABLE 2

Absolute" Number of Deaths and Percentage of Deaths from Each Cause for Each Job CATEgory

\begin{tabular}{|c|c|c|c|c|c|c|c|c|}
\hline \multicolumn{3}{|c|}{ Cause of death } & $\begin{array}{c}\text { Compositors, } \\
\text { readers, } \\
\text { foundrymen }\end{array}$ & $\begin{array}{l}\text { Machine } \\
\text { room } \\
\text { men }\end{array}$ & $\begin{array}{l}\text { Publishing } \\
\text { room } \\
\text { men }\end{array}$ & $\begin{array}{l}\text { Other } \\
\text { manual } \\
\text { workers }\end{array}$ & $\begin{array}{c}\text { All } \\
\text { printing } \\
\text { trade } \\
\text { workers }\end{array}$ & $\begin{array}{l}\text { White } \\
\text { collar } \\
\text { workers }\end{array}$ \\
\hline $\begin{array}{l}\text { All London companies } \\
\text { Cancer of lung and bronchus }\end{array}$ & . & No. & $\begin{array}{l}65 \\
12 \cdot 0\end{array}$ & $\begin{array}{l}71 \\
13 \cdot 2\end{array}$ & $\begin{array}{l}91 \\
15 \cdot 3\end{array}$ & $\begin{array}{l}53 \\
16 \cdot 3\end{array}$ & $\begin{array}{l}280 \\
14 \cdot 0\end{array}$ & $\begin{array}{l}73 \\
10 \cdot 7\end{array}$ \\
\hline $\begin{array}{l}\text { All malignant diseases except } \\
\text { lung and bronchus }\end{array}$ & $\begin{array}{ll}\text { cancer of } \\
\ldots \quad \ldots\end{array}$ & No. & $\begin{array}{l}77 \\
14 \cdot 2\end{array}$ & $\begin{array}{l}82 \\
15 \cdot 2\end{array}$ & $\begin{array}{l}88 \\
14 \cdot 8\end{array}$ & $\begin{array}{l}55 \\
16 \cdot 9\end{array}$ & $\begin{array}{l}302 \\
15 \cdot 1\end{array}$ & $\begin{array}{l}115 \\
16 \cdot 9\end{array}$ \\
\hline $\begin{array}{ccc}\text { Other respiratory } & \text { diseases } \\
\text { bronchitis } & . & \ldots\end{array}$ & $\begin{array}{l}\text { including } \\
\ldots \quad . .\end{array}$ & No. & $\begin{array}{l}64 \\
11 \cdot 8\end{array}$ & $\begin{array}{l}71 \\
13 \cdot 2\end{array}$ & $\begin{array}{l}94 \\
15 \cdot 8\end{array}$ & $\begin{array}{l}35 \\
10 \cdot 8\end{array}$ & $\begin{array}{l}264 \\
13 \cdot 2\end{array}$ & $\begin{array}{l}59 \\
8 \cdot 7\end{array}$ \\
\hline Heart and circulatory diseases & . & No. & $\begin{array}{l}212 \\
39 \cdot 2\end{array}$ & $\begin{array}{l}197 \\
36 \cdot 5\end{array}$ & $\begin{array}{l}214 \\
36 \cdot 0\end{array}$ & $\begin{array}{l}119 \\
36 \cdot 6\end{array}$ & $\begin{array}{l}742 \\
37 \cdot 1\end{array}$ & $\begin{array}{l}275 \\
40 \cdot 4\end{array}$ \\
\hline Diseases of nervous system & . & $\begin{array}{l}\text { No. } \\
\%\end{array}$ & $\begin{array}{l}59 \\
10 \cdot 9\end{array}$ & $\begin{array}{c}44 \\
8 \cdot 2\end{array}$ & $\begin{array}{l}50 \\
8 \cdot 4\end{array}$ & $\begin{array}{l}34 \\
10 \cdot 5\end{array}$ & $\begin{array}{l}187 \\
9 \cdot 4\end{array}$ & $\begin{array}{l}66 \\
9 \cdot 7\end{array}$ \\
\hline $\begin{array}{l}\text { All other causes including acc } \\
\text { suicides } \ldots\end{array}$ & $\begin{array}{c}\text { idents and } \\
\ldots \quad \ldots\end{array}$ & $\begin{array}{l}\text { No. } \\
\%\end{array}$ & $\begin{array}{l}64 \\
11 \cdot 8\end{array}$ & $\begin{array}{l}74 \\
13 \cdot 7\end{array}$ & $\begin{array}{l}57 \\
9 \cdot 6\end{array}$ & $\begin{array}{l}29 \\
8 \cdot 9\end{array}$ & $\begin{array}{l}224 \\
11 \cdot 2\end{array}$ & $\begin{array}{l}92 \\
13 \cdot 5\end{array}$ \\
\hline All causes .. & . & $\begin{array}{l}\text { No. } \\
\%\end{array}$ & $\begin{array}{l}541 \\
99 \cdot 9\end{array}$ & $\begin{array}{l}539 \\
100 \cdot 0\end{array}$ & $\begin{array}{l}594 \\
99 \cdot 9\end{array}$ & $\begin{array}{l}325 \\
100 \cdot 0\end{array}$ & $\begin{array}{l}1999 \\
100 \cdot 0\end{array}$ & $\begin{array}{l}680 \\
99 \cdot 9\end{array}$ \\
\hline
\end{tabular}

All Manchester companies

\begin{tabular}{|c|c|c|c|c|c|c|c|c|c|}
\hline Cancer of lung and bronchus & . & . & $\begin{array}{c}\text { No. } \\
\%\end{array}$ & $\begin{array}{c}16 \\
7 \cdot 3\end{array}$ & $\begin{array}{l}38 \\
18 \cdot 9\end{array}$ & $\begin{array}{l}22 \\
15.5\end{array}$ & $\stackrel{9}{10 \cdot 0}$ & $\begin{array}{l}85 \\
13 \cdot 0\end{array}$ & $\begin{array}{c}15 \\
9 \cdot 7\end{array}$ \\
\hline $\begin{array}{c}\text { All malignant diseases except } \\
\text { lung and bronchus }\end{array}$ & $\begin{array}{l}\text { cancer } \\
\text {. }\end{array}$ & $\begin{array}{l}\text { of } \\
\cdots\end{array}$ & No. & $\begin{array}{l}30 \\
13 \cdot 7\end{array}$ & $\begin{array}{l}21 \\
10 \cdot 4\end{array}$ & $\begin{array}{l}26 \\
18 \cdot 3\end{array}$ & $\begin{array}{l}8 \\
8 \cdot 9\end{array}$ & $\begin{array}{l}85 \\
13 \cdot 0\end{array}$ & $\begin{array}{l}20 \\
13 \cdot 0\end{array}$ \\
\hline $\begin{array}{ccc}\text { Other respiratory } & \text { diseases } \\
\text { bronchitis } & . & \ldots\end{array}$ & includin & & $\begin{array}{l}\text { No. } \\
\%\end{array}$ & $\begin{array}{l}19 \\
8 \cdot 7\end{array}$ & $\begin{array}{l}26 \\
12 \cdot 9\end{array}$ & $\begin{array}{l}22 \\
15 \cdot 5\end{array}$ & $\begin{array}{l}16 \\
17 \cdot 8\end{array}$ & $\begin{array}{l}83 \\
12 \cdot 7\end{array}$ & $\begin{array}{c}14 \\
9 \cdot 1\end{array}$ \\
\hline Heart and circulatory diseases & . & . . & No. & $\begin{array}{l}90 \\
41 \cdot 1\end{array}$ & $\begin{array}{l}65 \\
32 \cdot 3\end{array}$ & $\begin{array}{l}37 \\
26 \cdot 1\end{array}$ & $\begin{array}{l}36 \\
40 \cdot 0\end{array}$ & $\begin{array}{l}228 \\
35 \cdot 0\end{array}$ & $\begin{array}{l}57 \\
37 \cdot 0\end{array}$ \\
\hline Diseases of nervous system & . & . & No. & $\begin{array}{l}35 \\
16 \cdot 0\end{array}$ & $\begin{array}{l}22 \\
10 \cdot 9\end{array}$ & $\begin{array}{l}18 \\
12 \cdot 7\end{array}$ & $\begin{array}{l}11 \\
12 \cdot 2\end{array}$ & $\begin{array}{l}86 \\
13 \cdot 2\end{array}$ & $\begin{array}{l}24 \\
15 \cdot 6\end{array}$ \\
\hline $\begin{array}{l}\text { All other causes including acc } \\
\text { suicides } \ldots\end{array}$ & $\begin{array}{l}\text { idents ar } \\
\ldots\end{array}$ & $\begin{array}{l}\text { ind } \\
\cdots\end{array}$ & $\begin{array}{r}\text { No. } \\
\%\end{array}$ & $\begin{array}{l}29 \\
13 \cdot 2\end{array}$ & $\begin{array}{l}29 \\
14 \cdot 4\end{array}$ & $\begin{array}{l}17 \\
12 \cdot 0\end{array}$ & $\begin{array}{l}10 \\
11 \cdot 1\end{array}$ & $\begin{array}{l}85 \\
13 \cdot 0\end{array}$ & $\begin{array}{l}24 \\
15 \cdot 6\end{array}$ \\
\hline All causes & . & . & No. & $\begin{array}{l}219 \\
100 \cdot 0\end{array}$ & $\begin{array}{c}201 \\
99.8\end{array}$ & $\begin{array}{l}142 \\
100 \cdot 1\end{array}$ & $\begin{array}{c}90 \\
100.0\end{array}$ & $\begin{array}{c}652 \\
99.9\end{array}$ & $\begin{array}{l}154 \\
100.0\end{array}$ \\
\hline
\end{tabular}

In these calculations it is usual to use five-year age of death ranges, but the Registrar General does not publish data for conurbations which are sufficiently detailed for periods of less than 10 years to be used. The alternative method is to use the data for the whole of England and Wales, which are in five-year periods, and to correct for the standard mortality ratios of all deaths and of lung cancer deaths for the conurbations. The standard mortality ratios for the conurbations are given in the Registrar General's Tables for each calender year from 1963 onwards, but before that are given only for 1950-3 and 1959-63, so that some estimation is required in applying them to the five-year calendar periods $1952-6,1957-61$ and 
1962-6. The correction factors are considerable for the Greater London conurbation (about 1.31) but quite small for the South East Lancashire Conurbation (about 1.02). In two comparisons the two methods resulted in very close values for the expected number of deaths:

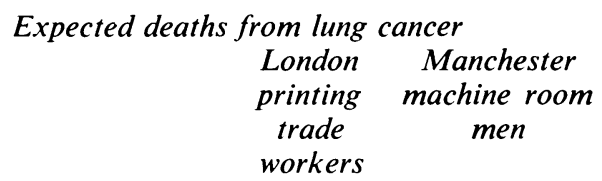

Expected calculated direct

from regional mortality

experience $\quad . \quad \quad$. $96 \cdot 2$

$15 \cdot 4$

Expected calculated from

E. \& W. mortality experience corrected by regional S.M.R.S .

$94 \cdot 9$

The comparison with regional mortality experience was preferred as being more direct, while the above comparisons indicate that it produces very similar results.

A cautious approach is necessary when comparing the observed and expected numbers of deaths from lung cancer because it is not certain that the records of deaths are complete and it has not been possible to take account of years of exposure. In addition, the expected numbers are based on proportional mortalities and not on mortality rates so that an apparent excess of deaths from lung cancer might possibly be due to an unusually low number of deaths from other causes rather than to a high number of deaths from lung cancer. It is, therefore, more prudent to take a $1 \%$ level of probability $(P=0.01)$ as indicative of a significant difference and to regard significance at a $5 \%$ level $(P=0.05)$ as merely suggestive.

The London companies The observed and expected deaths from cancer of the lung and bronchus in 1952-66 for the separate printing trade job groups in the individual London companies are compared in Table 3. There is nearly always an excess of observed over expected numbers of deaths. Only three of these excesses are significant at the $5 \%$ level (because of the number of comparisons being made, one value beyond the $5 \%$ point might be expected by chance). If, however, the four printing trade job groups are combined, eight of the nine companies have excesses of observed over expected deaths, two of the excesses (companies 01 and 03 ) being significant at the 5\% level, and one (company 16 ) at the $1 \%$ level.

When each job category is combined for all nine companies, two of the job categories, publishing room men and other manual workers, show excesses of $36 \%$ and $45 \%$ respectively, which are significant at the $1 \%$ level.
Combining all printing trade workers in all nine companies, the excess of observed (280) over expected $(212.5)$ deaths is $32 \%$ and is significant at the $1 \%$ level. ${ }^{1}$ With the white collar workers, on the other hand, five of the companies show excesses of observed over expected deaths and four the reverse, none of the differences being significant at the $5 \%$ level. Combining the white collar workers in the nine companies, there is virtually no difference between the observed (73) and the expected (72.8) numbers of deaths.

The Manchester companies The same comparison of observed and expected deaths from cancer of the lung and bronchus is made in Table 4 for the Manchester companies. As with the London companies, there is usually an excess of observed over expected deaths in the separate printing trade job groups of the individual companies, and three of these excesses are significant, two at the $5 \%$ level and one at the $1 \%$ level. All three are in machine room men and, if the machine room men are combined for all five companies, the excess of observed (38) over expected (18.7) deaths is $103 \%$ and is significant at the $1 \%$ level.

If the publishing room men in the five companies are combined, the excess of observed (22) over expected (13.7) deaths is $61 \%$ and is significant at the $5 \%$ level.

Combining the four printing trade groups in each company, four of the five companies have excesses of observed over expected deaths, one being significant at the $5 \%$ level.

When the printing trade workers are combined for all five companies, the excess of observed (85) over expected $(60.3)$ deaths is $41 \%$ and is significant at the $1 \%$ level.

With the white collar workers, however, only one of the companies has an excess of observed over expected deaths, one shows no difference, and three have an excess of expected over observed deaths, but the absolute numbers are very small. When the five companies are combined there is a $21 \%$ excess of observed (15) over expected (12.4) deaths which is not significant at the $5 \%$ level.

Manchester machine room men The three largest excesses of observed over expected deaths from cancer of the lung and bronchus occurred in the machine room men of three of the Manchester companies, and the machine room men in the other two Manchester companies also have excesses of observed deaths of over $40 \%$. In Table 5 the effect of separating the machine room men from the other

${ }^{1}$ After this survey was completed, H.M. Chief Inspector of Factories (1969) reported a $33 \%$ excess of deaths from carcinoma of the bronchus in a group of printing workers, 93 deaths observed as against 70 expected $(P<0.01)$. 
TABLE 3

Observed (O) And Expected (E) Deaths from Cancer of Lung and Bronchus, London Companies

\begin{tabular}{|c|c|c|c|c|c|c|c|c|}
\hline Company & $\begin{array}{l}\text { Total no. } \\
\text { of deaths } \\
\text { from all } \\
\text { causes }\end{array}$ & & $\begin{array}{c}\text { Compositors } \\
\text { readers, } \\
\text { foundrymen }\end{array}$ & $\begin{array}{l}\text { Machine } \\
\text { room } \\
\text { men }\end{array}$ & $\begin{array}{l}\text { Publishing } \\
\text { room } \\
\text { men }\end{array}$ & $\begin{array}{l}\text { Other } \\
\text { manual } \\
\text { workers }\end{array}$ & $\begin{array}{c}\text { All } \\
\text { printing } \\
\text { trade } \\
\text { workers }\end{array}$ & $\begin{array}{c}\text { White } \\
\text { collar } \\
\text { workers }\end{array}$ \\
\hline 01 & 1182 & $\begin{array}{c}O \\
\mathrm{E} \\
\mathrm{O} / \mathrm{E} \\
\mathrm{P}\end{array}$ & $\begin{array}{r}27 \\
23 \cdot 16 \\
1 \cdot 17\end{array}$ & $\begin{array}{l}30 \\
27 \cdot 13 \\
1 \cdot 11\end{array}$ & $\begin{array}{l}39 \\
31 \cdot 00 \\
1 \cdot 26\end{array}$ & $\begin{array}{r}23 \\
14.91 \\
1.54 \\
P<0.05\end{array}$ & $\begin{array}{r}119 \\
96.20 \\
1.24 \\
P<0.05\end{array}$ & $\begin{array}{r}33 \\
26 \cdot 49 \\
1 \cdot 25\end{array}$ \\
\hline 03 & 581 & $\begin{array}{c}O \\
E \\
O / E \\
P\end{array}$ & $\begin{array}{l}9 \\
6 \cdot 36 \\
1 \cdot 42\end{array}$ & $\begin{array}{l}23 \\
17 \cdot 02 \\
1 \cdot 35\end{array}$ & $\begin{array}{l}23 \\
18 \cdot 81 \\
1 \cdot 22\end{array}$ & $\begin{array}{l}17 \\
11.07 \\
1.54\end{array}$ & $\begin{array}{r}72 \\
53.26 \\
1.35 \\
\mathrm{P}<0.05\end{array}$ & $\begin{array}{c}4 \\
10 \cdot 01 \\
0.40\end{array}$ \\
\hline 04 & 210 & $\begin{array}{c}\mathbf{O} \\
\mathbf{E} \\
\mathbf{O} / \mathbf{E} \\
\mathbf{P}\end{array}$ & $\begin{array}{l}1 \\
2 \cdot 04 \\
0 \cdot 49\end{array}$ & $\begin{array}{l}3 \\
1 \cdot 73 \\
1 \cdot 74\end{array}$ & $\begin{array}{l}10 \\
6 \cdot 13 \\
1 \cdot 63\end{array}$ & $\begin{array}{l}3 \\
2 \cdot 80 \\
1 \cdot 07\end{array}$ & $\begin{array}{r}17 \\
12 \cdot 70 \\
1 \cdot 34\end{array}$ & $\begin{array}{l}11 \\
9 \cdot 68 \\
1 \cdot 14\end{array}$ \\
\hline 05 & 258 & $\begin{array}{c}\mathbf{O} \\
\mathbf{E} \\
\mathbf{O} / \mathbf{E} \\
\mathbf{P}\end{array}$ & $\begin{array}{l}8 \\
7 \cdot 03 \\
1 \cdot 14\end{array}$ & $\begin{array}{l}3 \\
3 \cdot 77 \\
0 \cdot 80\end{array}$ & $\begin{aligned} 9 \\
4 \cdot 15 \\
2 \cdot 17 \\
\mathrm{P}<0.05\end{aligned}$ & $\begin{array}{l}4 \\
3 \cdot 30 \\
1 \cdot 21\end{array}$ & $\begin{array}{r}24 \\
18 \cdot 25 \\
1 \cdot 32\end{array}$ & $\begin{array}{l}6 \\
7 \cdot 50 \\
0 \cdot 80\end{array}$ \\
\hline 07-09 & 56 & $\begin{array}{c}\mathbf{O} \\
\mathbf{E} \\
\mathbf{O} / \mathbf{E} \\
\mathbf{P}\end{array}$ & $\begin{array}{l}6 \\
3 \cdot 30 \\
1 \cdot 82\end{array}$ & $\begin{array}{l}0 \\
0 \\
-\end{array}$ & $\begin{array}{l}0 \\
0 \cdot 34 \\
0\end{array}$ & $\begin{array}{l}0 \\
0 \cdot 35 \\
0\end{array}$ & $\begin{array}{l}6 \\
3.99 \\
1.50\end{array}$ & $\begin{array}{l}4 \\
2 \cdot 34 \\
1 \cdot 71\end{array}$ \\
\hline 10 & 141 & $\begin{array}{c}\mathbf{O} \\
\mathrm{E} \\
\mathbf{O} / \mathbf{E} \\
\mathbf{P}\end{array}$ & $\begin{array}{l}6 \\
3 \cdot 87 \\
1 \cdot 55\end{array}$ & $\begin{array}{l}7 \\
4 \cdot 76 \\
1 \cdot 47\end{array}$ & $\begin{array}{l}2 \\
2 \cdot 12 \\
0 \cdot 94\end{array}$ & $\begin{array}{l}1 \\
1 \cdot 60 \\
0 \cdot 62\end{array}$ & $\begin{array}{l}16 \\
12 \cdot 35 \\
1 \cdot 30\end{array}$ & $\begin{array}{l}6 \\
4 \cdot 10 \\
1 \cdot 46\end{array}$ \\
\hline 12 & 40 & $\begin{array}{c}\mathbf{O} \\
\mathbf{E} \\
\mathbf{O} / \mathbf{E} \\
\mathbf{P}\end{array}$ & $\begin{array}{l}1 \\
1 \cdot 01 \\
0.99\end{array}$ & $\begin{array}{l}3 \\
1 \cdot 19 \\
2 \cdot 53\end{array}$ & $\begin{array}{l}2 \\
1.99 \\
1.01\end{array}$ & $\begin{array}{l}1 \\
0 \cdot 41 \\
2 \cdot 45\end{array}$ & $\begin{array}{l}7 \\
4 \cdot 60 \\
1 \cdot 52\end{array}$ & $\begin{array}{l}2 \\
0 \cdot 57 \\
3 \cdot 50\end{array}$ \\
\hline 15 & 64 & $\begin{array}{c}\mathbf{O} \\
\mathbf{E} \\
\mathbf{O} / \mathbf{E} \\
\mathbf{P}\end{array}$ & $\begin{array}{l}0 \\
0 \cdot 74 \\
0\end{array}$ & $\begin{array}{l}0 \\
0 \cdot 24 \\
0\end{array}$ & $\begin{array}{l}1 \\
0 \cdot 64 \\
1 \cdot 57\end{array}$ & $\begin{array}{l}1 \\
1 \cdot 12 \\
0.90\end{array}$ & $\begin{array}{l}2 \\
2 \cdot 74 \\
0 \cdot 73\end{array}$ & $\begin{array}{l}2 \\
5 \cdot 33 \\
0 \cdot 38\end{array}$ \\
\hline 16 & 147 & $\begin{array}{c}\mathbf{O} \\
\mathbf{E} \\
\mathrm{O} / \mathrm{E} \\
\mathbf{P}\end{array}$ & $\begin{array}{l}7 \\
4 \cdot 20 \\
1.67\end{array}$ & $\begin{array}{l}2 \\
1.42 \\
1.41\end{array}$ & $\begin{array}{r}5 \\
1.75 \\
2.86 \\
P<0.05\end{array}$ & $\begin{array}{l}3 \\
1 \cdot 02 \\
2 \cdot 95\end{array}$ & $\begin{array}{c}17 \\
8.39 \\
2.03 \\
P<0.01\end{array}$ & $\begin{array}{l}5 \\
6 \cdot 81 \\
0 \cdot 73\end{array}$ \\
\hline All & 2679 & $\begin{array}{c}\mathbf{O} \\
\mathrm{E} \\
\mathrm{O} / \mathrm{E} \\
\mathbf{P}\end{array}$ & $\begin{array}{l}65 \\
51 \cdot 71 \\
1.26\end{array}$ & $\begin{array}{r}71 \\
57 \cdot 26 \\
1 \cdot 24\end{array}$ & $\begin{array}{r}91 \\
66.93 \\
1.36 \\
P<0.01\end{array}$ & $\begin{aligned} & 53 \\
& 36.58 \\
& 1.45 \\
& \mathrm{P}<0.01\end{aligned}$ & $\begin{aligned} 280 \\
212.48 \\
1.32 \\
\mathrm{P}<0.01\end{aligned}$ & $\begin{array}{l}73 \\
72 \cdot 83 \\
1.00\end{array}$ \\
\hline
\end{tabular}

$\mathrm{E}>5 \quad \mathrm{P}$ based on $\chi^{2}$.

$\mathrm{E}<5 \quad \mathrm{P}$ based on Poisson frequency distribution.

$P$ is quoted only when it falls between the $5 \%$ and $1 \%$ significance levels $(P<0.05)$ or below the $1 \%$ significance level $(P<0.01)$.

printing trade workers is shown. The observed and expected numbers of deaths have been calculated for the other three printing trade job categories combined, i.e., all Manchester printing trade workers except the machine room men. When this is done, three of the companies show excesses of observed over expected deaths and two companies the reverse. For the five companies combined the 
TABLE 4

Observed (O) and Expected (E) Deaths from Cancer of Lung and Bronchus, Manchester COMPANIES

\begin{tabular}{|c|c|c|c|c|c|c|c|c|}
\hline Company & $\begin{array}{l}\text { Total no. } \\
\text { of deaths } \\
\text { from all } \\
\text { causes }\end{array}$ & & $\begin{array}{c}\text { Compositors, } \\
\text { readers, } \\
\text { foundrymen }\end{array}$ & $\begin{array}{c}\text { Machine } \\
\text { room } \\
\text { men }\end{array}$ & $\begin{array}{l}\text { Publishing } \\
\text { room } \\
\text { men }\end{array}$ & $\begin{array}{c}\text { Other } \\
\text { manual } \\
\text { workers }\end{array}$ & $\begin{array}{c}\text { All } \\
\text { printing } \\
\text { trade } \\
\text { workers }\end{array}$ & $\begin{array}{c}\text { White } \\
\text { collar } \\
\text { workers }\end{array}$ \\
\hline 02 & 198 & $\begin{array}{c}\mathrm{O} \\
\mathrm{E} \\
\mathrm{O} / \mathrm{E} \\
\mathbf{P}\end{array}$ & $\begin{array}{l}4 \\
3 \cdot 37 \\
1 \cdot 19\end{array}$ & $\begin{aligned} & 9 \\
& 4.48 \\
& 2.01 \\
& P<0.05\end{aligned}$ & $\begin{array}{l}6 \\
2 \cdot 96 \\
2 \cdot 02\end{array}$ & $\begin{array}{l}1 \\
1 \cdot 77 \\
0.56\end{array}$ & $\begin{aligned} & 20 \\
& 12.58 \\
& 1.59 \\
& \mathrm{P}<0.05\end{aligned}$ & $\begin{array}{l}2 \\
2 \cdot 80 \\
0 \cdot 71\end{array}$ \\
\hline 06 & 294 & $\begin{array}{c}\mathrm{O} \\
\mathrm{E} \\
\mathrm{O} / \mathrm{E} \\
\mathbf{P}\end{array}$ & $\begin{array}{c}1 \\
5 \cdot 66 \\
0 \cdot 18\end{array}$ & $\begin{aligned} & 13 \\
& 4.87 \\
& 2.67 \\
& P<0.01\end{aligned}$ & $\begin{array}{l}8 \\
4 \cdot 69 \\
1 \cdot 71\end{array}$ & $\begin{array}{l}2 \\
1.84 \\
1.09\end{array}$ & $\begin{array}{l}24 \\
17.06 \\
1.41\end{array}$ & $\begin{array}{l}6 \\
5.89 \\
1.02\end{array}$ \\
\hline 11 & 97 & $\begin{array}{c}\mathrm{O} \\
\mathrm{E} \\
\mathrm{O} / \mathrm{E} \\
\mathrm{P}\end{array}$ & $\begin{array}{l}2 \\
2 \cdot 33 \\
0.86\end{array}$ & $\begin{array}{r}7 \\
3.08 \\
2.27 \\
P<0.05\end{array}$ & $\begin{array}{l}3 \\
1 \cdot 14 \\
2 \cdot 63\end{array}$ & $\begin{array}{l}1 \\
1.46 \\
0.69\end{array}$ & $\begin{array}{l}13 \\
8.01 \\
1 \cdot 62\end{array}$ & $\begin{aligned} & 6 \\
& 1.77 \\
& 3.40 \\
& P<0.05\end{aligned}$ \\
\hline 13 & 71 & $\begin{array}{c}\mathrm{O} \\
\mathrm{E} \\
\mathrm{O} / \mathrm{E} \\
\mathbf{P}\end{array}$ & $\begin{array}{l}2 \\
1.97 \\
1.01\end{array}$ & $\begin{array}{l}3 \\
2 \cdot 12 \\
1 \cdot 42\end{array}$ & $\begin{array}{l}0 \\
1 \cdot 41 \\
0\end{array}$ & $\begin{array}{l}1 \\
1 \cdot 48 \\
0 \cdot 68\end{array}$ & $\begin{array}{l}6 \\
6.98 \\
0.86\end{array}$ & $\begin{array}{l}0 \\
0.67 \\
0\end{array}$ \\
\hline 14 & 146 & $\begin{array}{c}\mathrm{O} \\
\mathrm{E} \\
\mathrm{O} / \mathrm{E} \\
\mathbf{P}\end{array}$ & $\begin{array}{l}7 \\
6 \cdot 15 \\
1 \cdot 14\end{array}$ & $\begin{array}{l}6 \\
4 \cdot 15 \\
1 \cdot 45\end{array}$ & $\begin{array}{l}5 \\
3 \cdot 48 \\
1 \cdot 44\end{array}$ & $\begin{array}{l}4 \\
1.92 \\
2.09\end{array}$ & $\begin{array}{l}22 \\
15 \cdot 70 \\
1 \cdot 40\end{array}$ & $\begin{array}{l}1 \\
1.28 \\
0 \cdot 78\end{array}$ \\
\hline All & 806 & $\begin{array}{c}\mathrm{O} \\
\mathrm{E} \\
\mathrm{O} / \mathrm{E} \\
\mathbf{P}\end{array}$ & $\begin{array}{l}16 \\
19 \cdot 48 \\
0.82\end{array}$ & $\begin{array}{r}38 \\
18 \cdot 70 \\
2.03 \\
P<0.01\end{array}$ & $\begin{array}{r}22 \\
13 \cdot 68 \\
1.61 \\
P<0.05\end{array}$ & $\begin{array}{l}9 \\
8 \cdot 47 \\
1.06\end{array}$ & $\begin{array}{r}85 \\
60.33 \\
1.41 \\
P<0.01\end{array}$ & $\begin{array}{l}15 \\
12.41 \\
1.21\end{array}$ \\
\hline
\end{tabular}

E $>5 \quad P$ based on $\chi^{2}$.

$\mathrm{E}<5 \quad \mathrm{P}$ based on Poisson frequency distribution.

$P$ is quoted only when it falls between the $5 \%$ and $1 \%$ significance levels $(P<0.05)$ or below the $1 \%$ significance level $(P<0.01)$.

numbers are 47 observed and $41 \cdot 6$ expected deaths, an excess of $13 \%$. Assuming that this excess applies throughout the printing trade workers, the expected numbers for the machine room men can be increased in this proportion so that any additional effect of the machine room can be isolated. After this modification, one of the companies still shows a marked excess of observed over expected deaths $(136 \%$, significant at the $1 \%$ level), and the other four companies all show appreciable excesses (from $25 \%$ to $101 \%$ ).

Combining the five companies, the excess of observed (38) over expected (21.1) deaths, after correction for the excess assumed to be common to all printing trade workers, is $80 \%$ and is significant at the $1 \%$ level.

It thus appears likely that there was a significant excess of deaths from lung cancer associated with the Manchester machine room men additional to any general excess which may have occurred among all the printing trade workers in Manchester.

Size of company In Table 6 the number of deaths from all causes per year in each company has been used as the best available estimate of the size of the company over the period of interest. There is no evidence of any trend with size of company in the ratio of observed to expected deaths from cancer of the lung and bronchus for any of the four printing trade job groups or for all printing trade workers combined, or for the white collar workers.

The greater scatter in the values of the ratio of observed to expected deaths for the smaller companies is a reflection of the smaller numbers of observed and expected deaths involved.

Comparison of quinquennia Because lung cancer resulting from a possible occupational hazard takes 
TABLE 5

Observed and Expected Deaths from Cancer of Lung and Bronchus, Manchester Companies

\begin{tabular}{|c|c|c|c|c|c|}
\hline Company & & $\begin{array}{c}\text { All } \\
\text { printing trade } \\
\text { workers }\end{array}$ & $\begin{array}{l}\text { Machine room } \\
\text { men }\end{array}$ & $\begin{array}{l}\text { All printing trade } \\
\text { workers except } \\
\text { machine room men }\end{array}$ & $\begin{array}{l}\text { Machine room men } \\
\text { with } E \text { increased by } \\
\text { O/E ratio for all } P . T . \\
\text { workers except machine } \\
\text { room men }(1 \cdot 13)\end{array}$ \\
\hline 02 & $\begin{array}{c}O \\
E \\
O / E \\
P\end{array}$ & $\begin{array}{l}20 \\
12.58 \\
1.59 \\
<0.05\end{array}$ & $\begin{array}{r}9 \\
4.48 \\
2.01 \\
<0.05\end{array}$ & $\begin{array}{l}11 \\
8 \cdot 10 \\
1 \cdot 36\end{array}$ & $\begin{array}{l}9 \\
5 \cdot 06 \\
1 \cdot 78 \\
(0 \cdot 08)\end{array}$ \\
\hline 06 & $\begin{array}{c}\mathbf{O} \\
\mathrm{E} \\
\mathbf{O} / \mathbf{E} \\
\mathbf{P}\end{array}$ & $\begin{array}{l}24 \\
17.06 \\
1.41 \\
(0.09)\end{array}$ & $\begin{array}{r}13 \\
4.87 \\
2.67 \\
<0.01\end{array}$ & $\begin{array}{r}11 \\
12 \cdot 19 \\
0 \cdot 90\end{array}$ & $\begin{array}{r}13 \\
5.50 \\
2.36 \\
<0.01\end{array}$ \\
\hline 11 & $\begin{array}{c}\mathbf{O} \\
\mathbf{E} \\
\mathbf{O} / \mathbf{E} \\
\mathbf{P}\end{array}$ & $\begin{array}{c}13 \\
8.01 \\
1.62 \\
(0.08)\end{array}$ & $\begin{array}{r}7 \\
3.08 \\
2.27 \\
<0.05\end{array}$ & $\begin{array}{l}6 \\
4 \cdot 93 \\
1 \cdot 22\end{array}$ & $\begin{array}{l}7 \\
3 \cdot 48 \\
2 \cdot 01 \\
(0 \cdot 06)\end{array}$ \\
\hline 13 & $\begin{array}{c}\mathbf{O} \\
\mathbf{E} \\
\mathbf{O} / \mathbf{E} \\
\mathbf{P}\end{array}$ & $\begin{array}{l}6 \\
6 \cdot 98 \\
0 \cdot 86\end{array}$ & $\begin{array}{l}3 \\
2 \cdot 12 \\
1 \cdot 42\end{array}$ & $\begin{array}{l}3 \\
4 \cdot 86 \\
0 \cdot 62\end{array}$ & $\begin{array}{l}3 \\
2 \cdot 40 \\
1 \cdot 25\end{array}$ \\
\hline 14 & $\begin{array}{c}\mathbf{O} \\
\mathbf{E} \\
\mathbf{O} / \mathbf{E} \\
\mathbf{P}\end{array}$ & $\begin{array}{l}22 \\
15 \cdot 70 \\
1 \cdot 40\end{array}$ & $\begin{array}{l}6 \\
4 \cdot 15 \\
1 \cdot 45\end{array}$ & $\begin{array}{l}16 \\
11 \cdot 55 \\
1 \cdot 39\end{array}$ & $\begin{array}{l}6 \\
4 \cdot 69 \\
1 \cdot 28\end{array}$ \\
\hline All & $\begin{array}{c}\mathbf{O} \\
\mathrm{E} \\
\mathbf{O} / \mathbf{E} \\
\mathbf{P}\end{array}$ & $\begin{array}{l}85 \\
60.33 \\
1.41 \\
<0.01\end{array}$ & $\begin{array}{r}38 \\
18.70 \\
2.03 \\
<0.01\end{array}$ & $\begin{array}{r}47 \\
41 \cdot 63 \\
1 \cdot 13\end{array}$ & $\begin{array}{l}38 \\
21 \cdot 13 \\
1.80 \\
<0.01\end{array}$ \\
\hline
\end{tabular}

E $>5 \quad$ P based on $\chi 2$.

E $<5 \quad P$ based on Poisson frequency distribution.

$P$ is not quoted unless it falls below the $5 \%$ significance level $(P=0.05)$.

TABLE 6

Size of Company and Ratio O/E for Deaths from Cancer of Lung and Bronchus

\begin{tabular}{|c|c|c|c|c|c|c|c|c|c|}
\hline \multirow[b]{2}{*}{ Company } & \multirow{2}{*}{$\begin{array}{l}\text { Total } \\
\text { no. of } \\
\text { deaths } \\
\text { from all } \\
\text { causes }\end{array}$} & \multirow{2}{*}{$\begin{array}{l}\text { No. of } \\
\text { years over } \\
\text { which } \\
\text { deaths } \\
\text { spread }\end{array}$} & \multirow{2}{*}{$\begin{array}{l}\text { Deaths } \\
\text { from all } \\
\text { causes, } \\
\text { average } \\
\text { per year }\end{array}$} & \multicolumn{6}{|c|}{ O/E for deaths from cancer of lung and bronchus } \\
\hline & & & & $\begin{array}{c}\text { Compositors } \\
\text { readers, } \\
\text { foundrymen }\end{array}$ & $\begin{array}{l}\text { Machine } \\
\text { room } \\
\text { men }\end{array}$ & $\begin{array}{l}\text { Publishing } \\
\text { room } \\
\text { men }\end{array}$ & $\begin{array}{l}\text { Other } \\
\text { manual } \\
\text { workers }\end{array}$ & $\begin{array}{l}\text { All print- } \\
\text { ing trade } \\
\text { workers }\end{array}$ & $\begin{array}{l}\text { White } \\
\text { collar } \\
\text { workers }\end{array}$ \\
\hline 01 & 1182 & 15 & 79 & 1.2 & $1 \cdot 1$ & $1 \cdot 3$ & 1.5 & $1 \cdot 24$ & $1 \cdot 3$ \\
\hline 10 & 141 & $2 \frac{1}{2}$ & 56 & 1.6 & $1 \cdot 5$ & 0.9 & 0.6 & $1 \cdot 30$ & $1 \cdot 5$ \\
\hline 03 & $701^{2}$ & 15 & 47 & 1.4 & $1 \cdot 4$ & $1 \cdot 2$ & 1.5 & 1.35 & 0.4 \\
\hline 04 & $452^{2}$ & 15 & 30 & 0.5 & 1.7 & 1.6 & $1 \cdot 1$ & 1.34 & $1 \cdot 1$ \\
\hline 12 & 40 & $1 \frac{1}{2}$ & 27 & 1.0 & $2 \cdot 5$ & 1.0 & 2.5 & 1.52 & 3.5 \\
\hline 06 & 294 & 15 & 20 & 0.2 & $2 \cdot 7$ & 1.7 & $1 \cdot 1$ & 1.41 & $1 \cdot 0$ \\
\hline 16 & 147 & $7 \frac{1}{2}$ & 20 & 1.7 & $1 \cdot 4$ & 2.9 & 3.0 & 2.03 & 0.7 \\
\hline 05 & 258 & $15^{2}$ & 17 & $1 \cdot 1$ & 0.8 & $2 \cdot 2$ & 1.2 & $1 \cdot 32$ & 0.8 \\
\hline 02 & 198 & 15 & 13 & $1 \cdot 2$ & $2 \cdot 0$ & $2 \cdot 0$ & 0.6 & 1.59 & 0.7 \\
\hline 11 & 97 & 8 & 12 & 0.9 & $2 \cdot 3$ & $2 \cdot 6$ & 0.7 & 1.62 & $3 \cdot 4$ \\
\hline 14 & 146 & 12 & 12 & $1 \cdot 1$ & 1.5 & 1.4 & $2 \cdot 1$ & 1.40 & 0.8 \\
\hline 15 & $74^{2}$ & 12 & 6 & 0 & 0 & 1.6 & 0.9 & 0.73 & 0.4 \\
\hline 13 & 71 & 14 & 5 & 1.0 & $1 \cdot 4$ & 0 & 0.7 & 0.86 & 0 \\
\hline $07-09$ & 56 & 15 & 4 & $1 \cdot 8$ & - & 0 & 0 & $1 \cdot 50$ & $1 \cdot 7$ \\
\hline All & $3857^{2}$ & & & $1 \cdot 14$ & $1 \cdot 43$ & $1 \cdot 40$ & $1 \cdot 38$ & $1 \cdot 34$ & 1.03 \\
\hline
\end{tabular}

${ }^{1}$ Average number of deaths from all causes per year is a rough indication of size of company over the period of interest. ${ }^{2}$ Including part-time workers. 
some years to develop, it was thought possible that, if such a hazard were operating, a variation in working conditions (e.g., during wartime, 1939-45) might show in a difference between the three quinquennia 1952-6, 1957-61, 1962-6. In Table 7 the ratios of observed to expected deaths from cancer of the lung and bronchus for all printing trade workers are compared in each company for which records are available over the whole period 1952-66. There are no consistent differences between the ratios for the three quinquennia.

A similar comparison is made in Table 8 for the job groups with differences between observed and expected deaths which are significant at the $5 \%$ level. Again there are no consistent differences between the three quinquennia.

\section{Deaths from bronchitis}

The reason for the excess of lung cancer deaths in the printing trade workers cannot be deduced from the present survey. There are factors, not necessarily of an occupational nature, which might have caused the moderate excesses found. The most likely nonoccupational cause is excessive smoking. It would need only a small difference in smoking habits to account for a 30 to $40 \%$ excess of observed over expected deaths. Smoking habits could not be included in this survey, so that no direct information on this possible factor is available. If, however, excessive smoking were the cause, an excess of deaths from bronchitis might also be expected, as mortality from chronic bronchitis is increased by cigarette smoking to a similar extent (Royal College of Physicians, 1971).

An analysis of the deaths from bronchitis (I.C.D. 500-502) has been carried out in exactly the same way as the analysis of the deaths from cancer of the lung and bronchus. There were 271 deaths in all from bronchitis, made up as follows:

$$
\begin{array}{lrr}
\text { I.C.D. } 500 \text { Acute bronchitis } & \text { Deaths } & \% \\
501 \text { Bronchitis } & 13 & 4.8 \\
\begin{array}{c}
\text { unqualified } \ldots \\
502 \text { Chronic bronchitis }
\end{array} & 5 & 1 \cdot 8 \\
& 253 & 93 \cdot 4 \\
\hline & 271 & 100 \cdot 0
\end{array}
$$

The combined classification, bronchitis I.C.D. 500-502, has been used because the Registrar General's mortality statistics for the conurbations, from which the expected numbers of deaths from bronchitis have been calculated, are in this form. More than $90 \%$ of the combined deaths are from chronic bronchitis.

In Table 9 the absolute numbers of deaths and the

\begin{tabular}{|c|c|c|c|c|c|c|c|c|c|c|c|c|}
\hline \multirow{2}{*}{ Company } & \multicolumn{3}{|c|}{$1952-6$} & \multicolumn{3}{|c|}{$1957-61$} & \multicolumn{3}{|c|}{$1962-6$} & \multicolumn{3}{|c|}{$1952-66$} \\
\hline & $O$ & $E$ & $O / E$ & $O$ & $E$ & $O / E$ & $O$ & $E$ & $O / E$ & $O$ & $E$ & $O / E$ \\
\hline $\begin{array}{c}\text { London companies } \\
01 \\
03 \\
04 \\
05 \\
07-09 \\
15\end{array}$ & $\begin{array}{r}15 \\
18 \\
8 \\
2 \\
1 \\
1\end{array}$ & $\begin{array}{r}19 \cdot 88 \\
9 \cdot 58 \\
3.51 \\
2.56 \\
0.57 \\
0.20\end{array}$ & $\begin{array}{l}0.75 \\
1.88 \\
2.28 \\
0.78 \\
1.75 \\
5.00\end{array}$ & $\begin{array}{r}46 \\
19 \\
4 \\
4 \\
1 \\
1\end{array}$ & $\begin{array}{r}34 \cdot 85 \\
15.69 \\
3.80 \\
7 \cdot 37 \\
1 \cdot 15 \\
0.92\end{array}$ & $\begin{array}{l}1.32 \\
1.21 \\
1.05 \\
0.54 \\
0.87 \\
1.08\end{array}$ & $\begin{array}{r}58 \\
35 \\
5 \\
18 \\
4 \\
0\end{array}$ & $\begin{array}{r}41 \cdot 46 \\
28 \cdot 04 \\
5 \cdot 38 \\
8 \cdot 32 \\
2 \cdot 27 \\
1 \cdot 61\end{array}$ & $\begin{array}{r}1.40 \\
1.25 \\
0.93 \\
2.16 \\
1.76 \\
0\end{array}$ & $\begin{array}{r}119 \\
72 \\
17 \\
24 \\
6 \\
2\end{array}$ & $\begin{array}{r}96 \cdot 20 \\
53 \cdot 31 \\
12 \cdot 70 \\
18 \cdot 25 \\
3.99 \\
2.74\end{array}$ & $\begin{array}{l}1 \cdot 24 \\
1 \cdot 35 \\
1 \cdot 34 \\
1 \cdot 32 \\
1.50 \\
0.73\end{array}$ \\
\hline Above combined & 45 & $36 \cdot 30$ & $1 \cdot 24$ & 75 & $63 \cdot 78$ & $1 \cdot 18$ & 120 & $87 \cdot 08$ & $1 \cdot 38$ & 240 & $187 \cdot 20$ & $1 \cdot 28$ \\
\hline
\end{tabular}
percentage of deaths from bronchitis in each job

TABLE 7

Comparison of Quinquennia, Deaths from Cancer of Lung and Bronchus, all Printing TRADE WORKERS

Manchester companies

\begin{tabular}{c|r|r|r|r|r|r|r|r|r|r|r|r}
02 & 5 & 2.51 & 1.99 & 8 & 3.90 & 2.05 & 7 & 6.18 & 1.13 & 20 & 12.58 & 1.59 \\
13 & 6 & 3.36 & 1.78 & 6 & 5.77 & 1.04 & 12 & 7.93 & 1.51 & 24 & 17.06 & 1.41 \\
14 & 2 & 2.02 & 0.99 & 4 & 3.33 & 1.20 & 0 & 1.63 & 0 & 6 & 6.98 & 0.86 \\
15.70 & 1.40 \\
\hline $\begin{array}{c}\text { Above } \\
\text { combined }\end{array}$ & 1 & 2.01 & 0.50 & 11 & $7 \cdot 24$ & 1.52 & 10 & 6.45 & 1.55 & 22 & 15 \\
\hline
\end{tabular}

London and Manchester companies

\begin{tabular}{l|l|l|l|l|l|l|l|l|l|l|l|l}
$\begin{array}{c}\text { All above } \\
\text { combined }\end{array}$ & 59 & $46 \cdot 20$ & $1 \cdot 28$ & 104 & 84.02 & 1.24 & 149 & $109 \cdot 27$ & 1.36 & 312 & $239 \cdot 49$ & $1 \cdot 30$ \\
\hline
\end{tabular}


TABLE 8

Comparison of Quinquennia, DeATHS from CANCER of Lung and Bronchus, Job Groups With Significant Difference $(P<0.05)$ Between $O$ AND $E$

\begin{tabular}{|c|c|c|c|c|c|c|c|c|c|c|c|c|c|c|}
\hline \multirow{2}{*}{ Company } & \multirow{2}{*}{\multicolumn{2}{|c|}{ Job group }} & \multicolumn{3}{|c|}{$1952-56$} & \multicolumn{3}{|c|}{$1957-61$} & \multicolumn{3}{|c|}{$1962-66$} & \multicolumn{3}{|c|}{$1952-66$} \\
\hline & & & $O$ & $E$ & $O / E$ & $O$ & $E$ & $O / E$ & $O$ & $E$ & $O / E$ & $O$ & $E$ & $O / E$ \\
\hline $\begin{array}{c}\text { London compa } \\
01 \\
05 \\
16\end{array}$ & $\begin{array}{l}\text { nies } \\
\text { Other manual workers } \\
\text { Publishing room men } \\
\text { Publishing room men }\end{array}$ & $\begin{array}{l}\cdots \\
\cdots \\
\cdots\end{array}$ & $\begin{array}{l}4 \\
1\end{array}$ & $\begin{array}{c}3 \cdot 39 \\
0 \cdot 70 \\
10 \mathrm{recc}\end{array}$ & $\begin{array}{r}1 \cdot 18 \\
1 \cdot 43 \\
\text { ds }\end{array}$ & $\begin{array}{r}10 \\
3 \\
1\end{array}$ & $\begin{array}{l}5 \cdot 50 \\
1 \cdot 70 \\
0 \cdot 58\end{array}$ & $\begin{array}{l}1 \cdot 82 \\
1 \cdot 77 \\
1 \cdot 72\end{array}$ & $\begin{array}{l}9 \\
5 \\
4\end{array}$ & $\begin{array}{l}6 \cdot 02 \\
1 \cdot 75 \\
1 \cdot 17\end{array}$ & $\begin{array}{l}1 \cdot 50 \\
2 \cdot 85 \\
3 \cdot 43\end{array}$ & $\begin{array}{r}23 \\
9 \\
5\end{array}$ & $\begin{array}{r}14 \cdot 92 \\
4 \cdot 15 \\
1 \cdot 75\end{array}$ & $\begin{array}{l}1 \cdot 54 \\
2 \cdot 17 \\
2 \cdot 86\end{array}$ \\
\hline $\begin{array}{l}01 \text { and } 05 \\
\text { combined }\end{array}$ & As above .. $\ldots$ & $\ldots$ & 5 & $4 \cdot 09$ & $1 \cdot 22$ & 13 & $7 \cdot 20$ & $1 \cdot 81$ & 14 & $7 \cdot 77$ & $1 \cdot 80$ & 32 & $19 \cdot 07$ & $1 \cdot 68$ \\
\hline
\end{tabular}

Manchester companies

\begin{tabular}{|c|c|c|c|c|c|c|c|c|c|c|c|c|c|c|}
\hline $\begin{array}{l}02 \\
06 \\
11\end{array}$ & $\begin{array}{l}\text { Machine room men } \\
\text { Machine room men } \\
\text { Machine room men }\end{array}$ & $\begin{array}{l}\cdots \\
\cdots \\
\cdots\end{array}$ & $\begin{array}{l}3 \\
3\end{array}$ & $\begin{array}{c}1 \cdot 02 \\
1 \cdot 17\end{array}$ & $\begin{array}{l}2 \cdot 93 \\
2 \cdot 57 \\
\mathrm{ds}\end{array}$ & $\begin{array}{l}3 \\
2 \\
2\end{array}$ & $\begin{array}{l}1 \cdot 31 \\
0 \cdot 90 \\
0 \cdot 64\end{array}$ & $\begin{array}{l}2 \cdot 28 \\
2 \cdot 22 \\
3 \cdot 11\end{array}$ & $\begin{array}{l}3 \\
8 \\
5\end{array}$ & $\begin{array}{l}2 \cdot 15 \\
2 \cdot 80 \\
2 \cdot 44\end{array}$ & $\begin{array}{l}1 \cdot 40 \\
2 \cdot 85 \\
2 \cdot 05\end{array}$ & $\begin{array}{r}9 \\
13 \\
7\end{array}$ & $\begin{array}{l}4 \cdot 48 \\
4 \cdot 87 \\
3 \cdot 08\end{array}$ & $\begin{array}{l}2 \cdot 01 \\
2 \cdot 67 \\
2 \cdot 27\end{array}$ \\
\hline $\begin{array}{l}02 \text { and } 06 \\
\text { combined }\end{array}$ & As above .. & $\cdots$ & 6 & $2 \cdot 19$ & $2 \cdot 74$ & 5 & $2 \cdot 21$ & $2 \cdot 26$ & 11 & $4 \cdot 95$ & $2 \cdot 22$ & 22 & $9 \cdot 35$ & $2 \cdot 35$ \\
\hline
\end{tabular}

London and Manchester companies

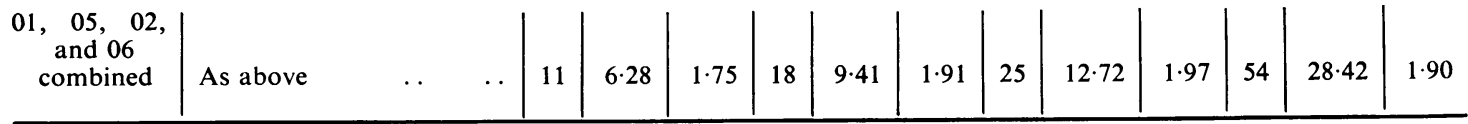

TABLE 9

Absolute Number of Deaths and Percentage of Deaths from Bronchitis (I.C.D. 500-502) AND From Other RespiratoRy Diseases (EXCluding Lung CANCER) FOR EACH JOB GROUP

\begin{tabular}{|c|c|c|c|c|c|c|c|}
\hline Cause of death & & $\begin{array}{c}\text { Compositors } \\
\text { readers, } \\
\text { foundrymen }\end{array}$ & $\begin{array}{l}\text { Machine } \\
\text { room } \\
\text { men }\end{array}$ & $\begin{array}{l}\text { Publishing } \\
\text { room } \\
\text { men }\end{array}$ & $\begin{array}{l}\text { Other } \\
\text { manual } \\
\text { workers }\end{array}$ & $\begin{array}{l}\text { All print- } \\
\text { ing trade } \\
\text { workers }\end{array}$ & $\begin{array}{l}\text { White } \\
\text { collar } \\
\text { workers }\end{array}$ \\
\hline 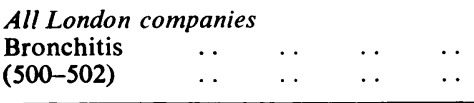 & $\begin{array}{c}\text { No. } \\
\%\end{array}$ & $\begin{array}{l}32 \\
5 \cdot 9\end{array}$ & $\begin{array}{l}44 \\
8 \cdot 2\end{array}$ & $\begin{array}{l}65 \\
10 \cdot 9\end{array}$ & $\begin{array}{l}22 \\
6 \cdot 8\end{array}$ & $\begin{array}{r}163 \\
8 \cdot 2\end{array}$ & $\begin{array}{l}40 \\
5 \cdot 9\end{array}$ \\
\hline $\begin{array}{l}\text { Other respiratoty diseases except cancer } \\
\text { of lung and bronchus }\end{array}$ & $\begin{array}{c}\text { No. } \\
\%\end{array}$ & $\begin{array}{l}32 \\
5 \cdot 9\end{array}$ & $\begin{array}{l}27 \\
5 \cdot 0\end{array}$ & $\begin{array}{l}29 \\
4 \cdot 9\end{array}$ & $\begin{array}{l}13 \\
4 \cdot 0\end{array}$ & $\begin{aligned} 101 \\
5 \cdot 1\end{aligned}$ & $\begin{array}{l}19 \\
2 \cdot 8\end{array}$ \\
\hline $\begin{array}{c}\text { All respiratory diseases except cancer } \\
\text { of lung and bronchus }\end{array}$ & $\begin{array}{c}\text { No. } \\
\%\end{array}$ & $\begin{array}{c}64 \\
11 \cdot 8\end{array}$ & $\begin{array}{l}71 \\
13 \cdot 2\end{array}$ & $\begin{array}{l}94 \\
15 \cdot 8\end{array}$ & $\begin{array}{l}35 \\
10 \cdot 8\end{array}$ & $\begin{array}{l}264 \\
13 \cdot 2\end{array}$ & $\begin{array}{l}59 \\
8 \cdot 7\end{array}$ \\
\hline 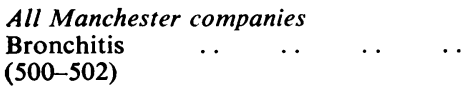 & $\begin{array}{c}\text { No. } \\
\%\end{array}$ & $\begin{array}{l}10 \\
4 \cdot 6\end{array}$ & $\begin{array}{l}18 \\
9 \cdot 0\end{array}$ & $\begin{array}{l}18 \\
12 \cdot 7\end{array}$ & $\begin{array}{l}13 \\
14 \cdot 4\end{array}$ & $\begin{array}{l}59 \\
9 \cdot 1\end{array}$ & $\begin{array}{l}9 \\
5 \cdot 8\end{array}$ \\
\hline $\begin{array}{l}\text { Other respiratory diseases except cancer } \\
\text { of lung and bronchus } \quad .\end{array}$ & $\begin{array}{c}\text { No. } \\
\%\end{array}$ & $\begin{array}{l}9 \\
4 \cdot 1\end{array}$ & $\begin{array}{l}8 \\
4 \cdot 0\end{array}$ & $\begin{array}{l}4 \\
2 \cdot 8\end{array}$ & $\begin{array}{l}3 \\
3 \cdot 3\end{array}$ & $\begin{array}{l}24 \\
3 \cdot 7\end{array}$ & $\begin{array}{l}5 \\
3 \cdot 3\end{array}$ \\
\hline $\begin{array}{l}\text { All respiratory diseases except cancer } \\
\text { of lung and bronchus }\end{array}$ & $\begin{array}{c}\text { No. } \\
\%\end{array}$ & $\begin{array}{c}19 \\
8 \cdot 7\end{array}$ & $\begin{array}{l}26 \\
12 \cdot 9\end{array}$ & $\begin{array}{l}22 \\
15 \cdot 5\end{array}$ & $\begin{array}{l}16 \\
17 \cdot 8\end{array}$ & $\begin{array}{l}83 \\
12 \cdot 7\end{array}$ & $\begin{array}{l}14 \\
9 \cdot 1\end{array}$ \\
\hline
\end{tabular}


category are given for the combined Manchester companies. Comparing the proportions of deaths from bronchitis in the four printing trade job categories with one another, the differences are statistically significant in the London companies $\left(\chi^{2}=10.62\right.$, D.F. $\left.=3,0.05>P>0.01\right)$. The publishing room men had the highest proportion of deaths from bronchitis (10.9\% of all deaths), and the compositors, readers, and foundrymen the lowest $(5.9 \%$ of all deaths). The corresponding differences in the Manchester companies are also statistically significant $\left(\chi^{2}=10 \cdot 80, \quad\right.$ D.F. $=3$, $0.05>\mathrm{P}>0.01$ ), the compositors, readers, and foundrymen again having the lowest proportion of deaths from bronchitis (4.6\% of all deaths).

The white collar workers had lower percentages of deaths from bronchitis than the combined printing trade workers both in the London and in the Manchester companies. Neither of these differences is significant at the $5 \%$ level.

As with the percentages of deaths from cancer of the lung and bronchus quoted in Table 2, the percentages of deaths from bronchitis in Table 9 are not corrected for differences in the ages at death or in the calendar dates of death.

The London companies In comparing the observed and expected numbers of deaths from bronchitis the same cautious approach is necessary as was adopted with the lung cancer deaths, and as before a $1 \%$ level of probability $(P=0.01)$ is taken as indicative of a significant difference. Significance at the $5 \%$ level $(\mathrm{P}=0.05)$ is regarded as merely suggestive.

The observed and expected deaths from bronchitis in 1952-66 for the separate printing trade job groups in the individual London companies are compared in Table 10. Sometimes there is an excess of observed over expected numbers of deaths, but more often there is a deficit. None of the individual differences is significant at the $5 \%$ level. If the four printing trade job groups are combined, eight of the nine companies show deficits of observed compared with expected deaths, and one a slight excess, but none of the differences is significant at the $5 \%$ level.

When each job category is combined for all nine companies, the publishing room men show an excess of $23 \%$ which is, however, not statistically significant, and the compositors, readers, and foundrymen show a deficit of $35 \%$ which is significant at the $5 \%$ level.

Combining all printing trade workers in all nine companies, the $8 \%$ deficit of observed (163) below expected $(177.6)$ deaths is not significant at the $5 \%$ level.

With the white collar workers, one company shows a deficit of observed compared with expected deaths which is significant at the $5 \%$ level; none of the other differences is statistically significant. Combining the white collar workers in the nine companies, the $29 \%$ deficit of observed (40) below expected (56.4) deaths is significant at the $5 \%$ level.

The Manchester companies The same comparison of observed and expected deaths from bronchitis is made in Table 11 for the Manchester companies. Taking the separate printing trade jobs in the individual companies, 10 of them show deficits and 10 excesses of observed over expected deaths from bronchitis. Only two of the differences, both deficits, are significant, one at the $5 \%$ and one at the $1 \%$ level. If the four printing trade job groups are combined, four of the five companies show deficits of observed compared with expected deaths, and one an excess, but none of the differences is significant at the $5 \%$ level.

When each job category is combined for all five companies, only the compositors, readers, and foundrymen show a significant difference-a 56\% deficit which is significant at the $1 \%$ level.

Combining all printing trade workers in all five companies, there is a $15 \%$ deficit of observed (59) compared with expected $(69 \cdot 1)$ deaths which is not significant at the $5 \%$ level.

With the white collar workers the numbers are very small, but when all five companies are combined there is a $44 \%$ deficit of observed (9) compared with expected $(16.0)$ deaths which is not, however, significant at the $5 \%$ level.

\section{Comparison with lung cancer excesses}

The largest excesses of observed over expected deaths from cancer of the lung and bronchus occurred in the Manchester machine room men, the excess for the five companies combined being $103 \%$ and significant at the $1 \%$ level. The same combined group showed a deficit of $17 \%$ in deaths from bronchitis, which is not statistically significant.

A comparison of individual ratios of observed to expected deaths from cancer of the lung and bronchus with the corresponding ratios for deaths from bronchitis shows no obvious relation between them.

Thus, there appears to be a small deficit of observed compared with expected deaths from bronchitis in workers in the newspaper industry for the period 1952-66. The deficit is about $10 \%$ for printing trade workers and 30 to $40 \%$ for white collar workers. There is little difference between the London and the Manchester companies. The deficits are not sufficiently great to be statistically significant because of the small numbers involved. Nevertheless, it seems unlikely that there could have been an excess of deaths from chronic bronchitis.

This analysis of the deaths from chronic bronchitis, therefore, does not support the view that excessive smoking was the cause of the moderate excesses of lung cancer deaths. 
TABLE 10

Observed (O) and Expected (E) Deaths from Bronchitis (I.C.D. 500-502), London Companies

\begin{tabular}{|c|c|c|c|c|c|c|c|c|}
\hline Company & $\begin{array}{l}\text { Total no. } \\
\text { of deaths } \\
\text { from all } \\
\text { causes }\end{array}$ & & $\begin{array}{l}\text { Compositors, } \\
\text { readers, } \\
\text { foundrymen }\end{array}$ & $\begin{array}{l}\text { Machine } \\
\text { room } \\
\text { men }\end{array}$ & $\begin{array}{c}\text { Publishing } \\
\text { room } \\
\text { men }\end{array}$ & $\begin{array}{l}\text { Other } \\
\text { manual } \\
\text { workers }\end{array}$ & $\begin{array}{l}\text { All } \\
\text { printing } \\
\text { trade } \\
\text { workers }\end{array}$ & $\begin{array}{l}\text { White } \\
\text { collar } \\
\text { workers }\end{array}$ \\
\hline 01 & 1182 & $\begin{array}{c}\mathbf{O} \\
\mathbf{E} \\
\mathbf{O} / \mathbf{E} \\
\mathbf{P}\end{array}$ & $\begin{array}{r}15 \\
23 \cdot 13 \\
0.65\end{array}$ & $\begin{array}{l}26 \\
22 \cdot 11 \\
1 \cdot 18\end{array}$ & $\begin{array}{l}35 \\
25 \cdot 17 \\
1 \cdot 39\end{array}$ & $\begin{array}{l}11 \\
12.55 \\
0.88\end{array}$ & $\begin{array}{l}87 \\
82 \cdot 96 \\
1.05\end{array}$ & $\begin{array}{r}12 \\
21.69 \\
0.55 \\
P<0.05\end{array}$ \\
\hline 03 & 581 & $\begin{array}{c}O \\
E \\
O / E \\
P\end{array}$ & $\begin{array}{l}5 \\
6 \cdot 08 \\
0 \cdot 82\end{array}$ & \begin{tabular}{r}
\multicolumn{1}{c}{8} \\
$14 \cdot 08$ \\
$0 \cdot 57$
\end{tabular} & $\begin{array}{l}20 \\
14 \cdot 09 \\
1 \cdot 42\end{array}$ & $\begin{array}{l}4 \\
8 \cdot 30 \\
0 \cdot 48\end{array}$ & $\begin{array}{l}37 \\
42 \cdot 55 \\
0.87\end{array}$ & $\begin{array}{l}8 \\
6 \cdot 65 \\
1 \cdot 20\end{array}$ \\
\hline 04 & 210 & $\begin{array}{c}\mathbf{O} \\
\mathbf{E} \\
\mathbf{O} / \mathbf{E} \\
\mathbf{P}\end{array}$ & $\begin{array}{l}2 \\
2 \cdot 15 \\
0.93\end{array}$ & $\begin{array}{l}1 \\
1 \cdot 74 \\
0 \cdot 57\end{array}$ & $\begin{array}{l}3 \\
5.06 \\
0.59\end{array}$ & $\begin{array}{l}4 \\
2 \cdot 41 \\
1 \cdot 66\end{array}$ & $\begin{array}{l}10 \\
11 \cdot 36 \\
0.88\end{array}$ & $\begin{array}{l}8 \\
7 \cdot 79 \\
1 \cdot 03\end{array}$ \\
\hline 05 & 258 & $\begin{array}{c}O \\
E \\
O / E \\
P\end{array}$ & $\begin{array}{l}5 \\
7 \cdot 05 \\
0 \cdot 71\end{array}$ & $\begin{array}{l}2 \\
3 \cdot 10 \\
0 \cdot 65\end{array}$ & $\begin{array}{l}3 \\
3 \cdot 84 \\
0 \cdot 78\end{array}$ & $\begin{array}{l}1 \\
2 \cdot 43 \\
0 \cdot 41\end{array}$ & $\begin{array}{l}11 \\
16 \cdot 42 \\
0 \cdot 67\end{array}$ & $\begin{array}{l}3 \\
6 \cdot 30 \\
0 \cdot 48\end{array}$ \\
\hline 07-09 & 56 & $\begin{array}{c}\mathbf{O} \\
\mathrm{E} \\
\mathbf{O} / \mathrm{E} \\
\mathbf{P}\end{array}$ & $\begin{array}{l}0 \\
2 \cdot 37 \\
0\end{array}$ & $\begin{array}{l}0 \\
0 \\
-\end{array}$ & $\begin{array}{l}0 \\
0 \cdot 21 \\
0\end{array}$ & $\begin{array}{l}0 \\
0 \cdot 22 \\
0\end{array}$ & $\begin{array}{l}0 \\
2 \cdot 80 \\
0\end{array}$ & $\begin{array}{l}1 \\
1 \cdot 71 \\
0 \cdot 59\end{array}$ \\
\hline 10 & 141 & $\begin{array}{c}\mathbf{O} \\
\mathbf{E} \\
\mathbf{O} / \mathbf{E} \\
\mathbf{P}\end{array}$ & $\begin{array}{l}2 \\
3 \cdot 19 \\
0.63\end{array}$ & $\begin{array}{l}4 \\
3 \cdot 45 \\
1 \cdot 16\end{array}$ & $\begin{array}{l}2 \\
1 \cdot 60 \\
1 \cdot 25\end{array}$ & $\begin{array}{l}0 \\
0 \cdot 88 \\
0\end{array}$ & $\begin{array}{l}8 \\
9 \cdot 12 \\
0 \cdot 88\end{array}$ & $\begin{array}{l}3 \\
2 \cdot 91 \\
1 \cdot 03\end{array}$ \\
\hline 12 & 40 & $\begin{array}{c}\mathbf{O} \\
\mathbf{E} \\
\mathbf{O} / \mathbf{E} \\
\mathbf{P}\end{array}$ & $\begin{array}{l}1 \\
0 \cdot 86 \\
1 \cdot 17\end{array}$ & $\begin{array}{l}1 \\
0 \cdot 88 \\
1 \cdot 14\end{array}$ & $\begin{array}{l}1 \\
1 \cdot 10 \\
0.91\end{array}$ & $\begin{array}{l}0 \\
0 \cdot 30 \\
0\end{array}$ & $\begin{array}{l}3 \\
3 \cdot 14 \\
0 \cdot 96\end{array}$ & $\begin{array}{l}0 \\
0 \cdot 47 \\
0\end{array}$ \\
\hline 15 & 64 & $\begin{array}{c}\mathbf{O} \\
\mathbf{E} \\
\mathbf{O} / \mathbf{E} \\
\mathbf{P}\end{array}$ & $\begin{array}{l}0 \\
0 \cdot 43 \\
0\end{array}$ & $\begin{array}{l}0 \\
0 \cdot 24 \\
0\end{array}$ & $\begin{array}{l}0 \\
0 \cdot 46 \\
0\end{array}$ & $\begin{array}{l}0 \\
0 \cdot 73 \\
0\end{array}$ & $\begin{array}{l}0 \\
1 \cdot 86 \\
0\end{array}$ & $\begin{array}{l}2 \\
3.06 \\
0.65\end{array}$ \\
\hline 16 & 147 & $\begin{array}{c}\mathbf{O} \\
\mathrm{E} \\
\mathbf{O} / \mathrm{E} \\
\mathbf{P}\end{array}$ & $\begin{array}{l}2 \\
3.66 \\
0.55\end{array}$ & $\begin{array}{l}2 \\
1 \cdot 36 \\
1 \cdot 47\end{array}$ & $\begin{array}{l}1 \\
1 \cdot 50 \\
0.67\end{array}$ & $\begin{array}{l}2 \\
0 \cdot 84 \\
2 \cdot 39\end{array}$ & $\begin{array}{l}7 \\
7 \cdot 36 \\
0 \cdot 95\end{array}$ & $\begin{array}{l}3 \\
5 \cdot 79 \\
0 \cdot 52\end{array}$ \\
\hline All & 2679 & $\begin{array}{c}\mathbf{O} \\
\mathbf{E} \\
\mathbf{O} / \mathbf{E} \\
\mathbf{P}\end{array}$ & $\begin{array}{r}32 \\
48.92 \\
0.65 \\
P<0.05\end{array}$ & $\begin{array}{r}44 \\
46.96 \\
0.94\end{array}$ & $\begin{array}{l}65 \\
53.03 \\
1.23\end{array}$ & $\begin{array}{r}22 \\
28 \cdot 66 \\
0 \cdot 77\end{array}$ & $\begin{array}{r}163 \\
177 \cdot 57 \\
0.92\end{array}$ & $\begin{array}{r}40 \\
56.37 \\
0.71 \\
P<0.05\end{array}$ \\
\hline
\end{tabular}

E $>5 \quad P$ based on $\chi^{2}$.

E $<5 \quad$ P based on Poisson frequency distribution.

$P$ is quoted only when it falls between the $5 \%$ and $1 \%$ significance levels $(P<0.05)$ or below the $1 \%$ significance level $(P<0.01)$.

Conclusion

There appears to be a small excess of observed over expected deaths from cancer of the lung and bronchus in newspaper printing trade workers (i.e., excluding white collar workers) for the period 1952-66. The excess is about $30 \%$ for the combined London companies and about $40 \%$ for the Manchester companies. Both these excesses are statistically significant at the $1 \%$ level. This survey does not provide any evidence about the cause of the overall 
TABLE 11

Observed (O) and Expected (E) Deaths from Bronchitis (I.C.D. 500-502), Manchester Companies

\begin{tabular}{|c|c|c|c|c|c|c|c|c|}
\hline Company & $\begin{array}{c}\text { Total no. } \\
\text { of deaths } \\
\text { from all } \\
\text { causes }\end{array}$ & & $\begin{array}{c}\text { Compositors, } \\
\text { readers, } \\
\text { foundrymen }\end{array}$ & $\begin{array}{l}\text { Machine } \\
\text { room } \\
\text { men }\end{array}$ & $\begin{array}{l}\text { Publishing } \\
\text { room } \\
\text { men }\end{array}$ & $\begin{array}{l}\text { Other } \\
\text { manual } \\
\text { workers }\end{array}$ & $\begin{array}{c}\text { All } \\
\text { printing } \\
\text { trade } \\
\text { workers }\end{array}$ & $\begin{array}{l}\text { White } \\
\text { collar } \\
\text { workers }\end{array}$ \\
\hline 02 & 198 & $\begin{array}{c}\mathrm{O} \\
\mathrm{E} \\
\mathbf{O} / \mathrm{E} \\
\mathbf{P}\end{array}$ & $\begin{array}{l}2 \\
5 \cdot 25 \\
0 \cdot 38\end{array}$ & $\begin{array}{r}1 \\
6.15 \\
0.16 \\
P<0.05\end{array}$ & $\begin{array}{l}5 \\
3 \cdot 73 \\
1 \cdot 34\end{array}$ & $\begin{array}{l}2 \\
2 \cdot 11 \\
0 \cdot 95\end{array}$ & $\begin{array}{l}10 \\
17 \cdot 24 \\
0.58\end{array}$ & $\begin{array}{l}6 \\
4 \cdot 15 \\
1 \cdot 45\end{array}$ \\
\hline 06 & 294 & $\begin{array}{c}\mathbf{O} \\
\mathbf{E} \\
\mathbf{O} / \mathrm{E} \\
\mathbf{P}\end{array}$ & $\begin{aligned} & 0 \\
7.52 & \\
& 0 \\
P< & 0.01\end{aligned}$ & $\begin{array}{l}6 \\
6 \cdot 79 \\
0 \cdot 88\end{array}$ & $\begin{array}{l}7 \\
6 \cdot 53 \\
1 \cdot 07\end{array}$ & $\begin{array}{l}5 \\
2 \cdot 66 \\
1 \cdot 88\end{array}$ & $\begin{array}{l}18 \\
23 \cdot 50 \\
0 \cdot 77\end{array}$ & $\begin{array}{l}3 \\
8 \cdot 20 \\
0 \cdot 37\end{array}$ \\
\hline 11 & 97 & $\begin{array}{c}\mathbf{O} \\
\mathbf{E} \\
\mathbf{O} / \mathrm{E} \\
\mathbf{P}\end{array}$ & $\begin{array}{l}4 \\
2 \cdot 89 \\
1 \cdot 38\end{array}$ & $\begin{array}{l}4 \\
2 \cdot 79 \\
1 \cdot 43\end{array}$ & $\begin{array}{l}2 \\
0 \cdot 92 \\
2 \cdot 18\end{array}$ & $\begin{array}{l}3 \\
1 \cdot 31 \\
2 \cdot 30\end{array}$ & $\begin{array}{l}13 \\
7 \cdot 91 \\
1 \cdot 64\end{array}$ & $\begin{array}{l}0 \\
1 \cdot 74 \\
0\end{array}$ \\
\hline 13 & 71 & $\begin{array}{c}\mathbf{O} \\
\mathbf{E} \\
\mathbf{O} / \mathbf{E} \\
\mathbf{P}\end{array}$ & $\begin{array}{l}0 \\
1 \cdot 90 \\
0\end{array}$ & $\begin{array}{l}2 \\
2 \cdot 30 \\
0 \cdot 87\end{array}$ & $\begin{array}{l}2 \\
1 \cdot 28 \\
1 \cdot 57\end{array}$ & $\begin{array}{l}2 \\
1 \cdot 38 \\
1 \cdot 45\end{array}$ & $\begin{array}{l}6 \\
6 \cdot 86 \\
0 \cdot 87\end{array}$ & $\begin{array}{l}0 \\
0 \cdot 86 \\
0\end{array}$ \\
\hline 14 & 146 & $\begin{array}{c}\mathbf{O} \\
\mathbf{E} \\
\mathbf{O} / \mathrm{E} \\
\mathbf{P}\end{array}$ & $\begin{array}{l}4 \\
5 \cdot 28 \\
0 \cdot 76\end{array}$ & $\begin{array}{l}5 \\
3 \cdot 68 \\
1 \cdot 36\end{array}$ & $\begin{array}{l}2 \\
3.03 \\
0.66\end{array}$ & $\begin{array}{l}1 \\
1.55 \\
0.65\end{array}$ & $\begin{array}{r}12 \\
13 \cdot 54 \\
0 \cdot 89\end{array}$ & $\begin{array}{l}0 \\
1 \cdot 05 \\
0\end{array}$ \\
\hline All & 806 & $\begin{array}{c}\mathbf{O} \\
\mathrm{E} \\
\mathbf{O} / \mathrm{E} \\
\mathbf{P}\end{array}$ & $\begin{array}{rl} & 10 \\
& 22.84 \\
& 0.44 \\
\mathrm{P}<0.01 & 0.01\end{array}$ & $\begin{array}{l}18 \\
21 \cdot 71 \\
0 \cdot 83\end{array}$ & $\begin{array}{l}18 \\
15 \cdot 49 \\
1 \cdot 16\end{array}$ & $\begin{array}{l}13 \\
9 \cdot 01 \\
1 \cdot 44\end{array}$ & $\begin{array}{l}59 \\
69 \cdot 05 \\
0.85\end{array}$ & $\begin{array}{l}9 \\
16 \cdot 00 \\
0.56\end{array}$ \\
\hline
\end{tabular}

$E>5 \quad P$ based on $\chi^{2}$.

$\mathrm{E}<5 \quad \mathrm{P}$ based on Poisson frequency distribution.

$\mathrm{P}$ is quoted only when it falls between the $5 \%$ and $1 \%$ significance levels $(\mathrm{P}<0.05)$ or below the $1 \%$ significance level $(\mathrm{P}<0.01)$.

small excess, which might or might not be occupational. The white collar workers show no excess in the London companies and the small excess in the Manchester companies is not statistically significant. Because of the latent period in the development of lung cancer, excesses of deaths from it found in the newspaper printing trade workers in 1952-66 must be presumed to relate to circumstances which were in existence many years earlier.

In the London companies there is no concentration of excess in any particular job group, but in Manchester the excess is more marked in the machine room men than elsewhere, being $103 \%$ and significant at the $1 \%$ level. When this excess in the Manchester machine room men is isolated from the excess assumed to be common to all printing trade workers in Manchester it is $80 \%$ and still significant at the $1 \%$ level. This excess might be due to non-occupational factors, but it seems more likely that the Manchester machine room men encountered some occupational hazard, the nature of which cannot be identified from this survey. Ask-Upmark (1955) attempted to show an association between lung cancer deaths and exposure to printing ink, which is greatest in the machine rooms where ink spray and fly are generated by the rotating rollers of the printing machines (Askew, 1958).

The excesses in lung cancer deaths in printing trade workers should be compared with excesses which have been found in surveys of other industrial groups in which a hazard of lung cancer has been accepted as proved. Bidstrup and Case (1956) found a $260 \%$ excess in workers in the bichromatesproducing industry; Doll (1958) reported an excess of $400 \%$ in nickel-refining workers; Knox, Holmes, Doll, and Hill (1968) found an excess of $900 \%$ in asbestos workers who were exposed for 10 or more years before the introduction of the Asbestos Regulations in 1933 . A $70 \%$ increase in retort house workers in the gas industry was described as 'not large' by Doll and his co-workers (1965). Bidstrup and Case (1956) were able to discount smoking as 
the sole cause of their $260 \%$ excess. No information on the smoking habits of those who had died was reported in the other studies.

Although the excess of deaths from cancer of the lung relates to conditions, whether occupational or not, up to 40 years previously, it cannot be presumed that the risk is no longer operating, and a prospective study would be required to determine the continuing existence of a hazard.

We are grateful to The Newspaper Publishers Association Ltd. for a grant in support of this work and for arranging the provision of data from their individual members. Our thanks are due also to Dr. J. R. Bowker, honorary lecturer in the Department of Occupational Health, University of Manchester, for suggestions and advice in the early stages of the investigation, and to Dr. M. R. Alderson, senior lecturer in the Department of Social and Preventive Medicine, University of Manchester, and now professor of medical information science, University of Southampton, for statistical advice.

\section{References}

Ask-Upmark, E. (1955). Bronchial carcinoma in printing workers. Dis. Chest, 27, 427-435.

Askew, F. A. (1958). Ink fly. Printing Technology, 2, no. 1, pp. 24-39.

Bidstrup, P. L., and Case, R. A. M. (1956). Carcinoma of the lung in workmen in the bichromates-producing industry in Great Britain. Brit. J. industr. Med., 13, 260-264.

Doll, R. (1958). Cancer of the lung and nose in nickel workers. Brit. J. industr. Med., 15, 217-223.

- Fisher, R. E. W., Gammon, E. J., Gunn, W., Hughes, G. O., Tyrer, F. H., and Wilson, W. (1965). Mortality of gasworkers with special reference to cancers of the lung and bladder, chronic bronchitis and pneumoconiosis. Brit. J. industr. Med., 22, 1-12.

Dunn, J. E., and Weir, J. M. (1968). A prospective study of mortality of several occupational groups. Arch. environm. Hlth, 17, 71-76.

H.M. Chief Inspector of Factories (1970). Annual Report, 1969, pp. 57-58.

Kennaway, E. L., and Kennaway, N. M. (1947). A further study of the incidence of cancer of the lung and larynx. Brit. J. Cancer, 1, 260-298.

Knox, J. F., Holmes, S., Doll, R., and Hill, I. D. (1968). Mortality from lung cancer and other causes among workers in an asbestos textile factory. Brit. J. industr. Med., 25, 293-303.

Registrar General (1938). Decennial Supplement, England and Wales, 1931, Part IIa Occupational Mortality, pp. 114-115. - (1958). Decennial Supplement, England and Wales 1951, Occupational Mortality, Part II, vol. I, p. 116.

Royal College of Physicians (1971). Smoking and Health Now, Chapter 5. Pitman Medical \& Scientific Publishing, London.

Appendix A

The main occupations included in the five job categories are:

Printing trade workers

1. Compositors, linotype operators, composing room assistants

Readers, reading room assistants

Foundrymen, bench and moulding staff, casting crew, stereotypers

2. Machine room men, machine managers, machine minders, machine room assistants, magazine room men, reel hands

3. Publishing room men, indoor and outdoor

4. Other manual workers

Production, process workers, etchers

Maintenance, electricians, engineers, linotype mechanics, maintenance cleaners

\section{White collar workers}

5. Office workers and staff, editors, sub-editors, journalists, reporters, circulation representatives, telegraph and communications staff, clerks, messengers

\section{Appendix B}

Malignant neoplasms mentioned in a subsidiary rôle and not coded as the underlying cause of death

The sites of the cancers and the commonest underlying causes of death in the 38 cases are detailed below. Six of the 38 certificates mentioned cancer of the lung and bronchus in the subsidiary rôle. In two of these six cases - a compositor and a process worker-the lung cancer was described as secondary to primary cancers sited in the prostate and the stomach respectively. The other four cases were as follows:

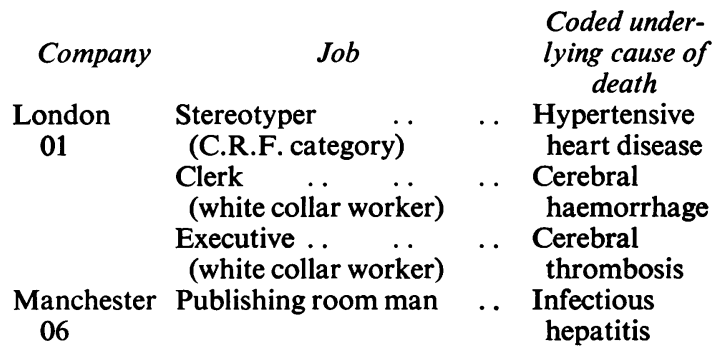

When these four cases $(0.9 \%$ of all 453 lung cancer deaths) were included as deaths from cancer of the lung and bronchus, the effect on the results was very small. The ratios of observed to expected deaths concerned were increased slightly, but the probability $(P)$ values quoted in Tables 3 and 4 were unchanged.

The malignant neoplasms mentioned in a subsidiary role were sited in:

Prostate 12

Large intestine and rectum 7

Bronchus and lung

Stomach

Bladder

Tongue

Floor of mouth

Tonsil

Pharynx

Skin

Unspecified

$$
\begin{aligned}
& 7 \\
& 6 \\
& 4 \\
& 4 \\
& 1 \\
& 1 \\
& 1 \\
& 1 \\
& 1 \\
& 1
\end{aligned}
$$

$$
\begin{gathered}
\overline{39} \text { ( } 2 \text { sites mentioned in one } \\
\text { case) }
\end{gathered}
$$

The coded causes of death in the 38 cases were mainly diseases of the heart and circulatory system (18 including 11 coronary), vascular lesions affecting the central nervous system (9), and diseases of the respiratory system other than cancer of the lung and bronchus (8).

Received for publication February 5, 1971. 